
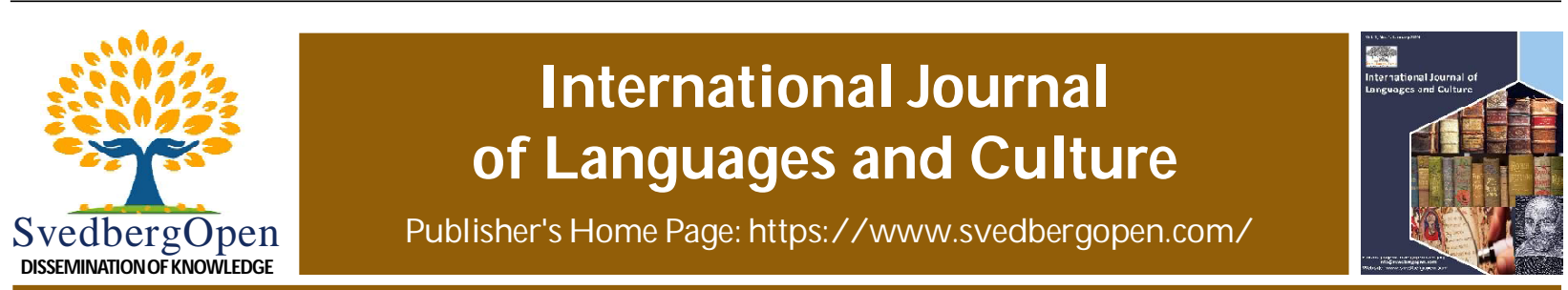

Research Paper

O pen A ccess

\title{
Using children's literature to combat corruption and insecurity in Nigeria
}

\author{
Nnawuihe Fidelis Echendu ${ }^{1 *}$ \\ 'Department of Languages, Federal Polytechnic Bida, Nigeria. E-mail: echendu.fidelis@fedpoly.edu.ng
}

\section{Article Info}

Volume 1, Issue 2, June 2021

Received : 12 November 2020

Accepted : 09 May 2021

Published : 05 June 2021

doi: 10.51483/IJLC.1.2.2021.14-18

\begin{abstract}
This paper explored the role of literature in the moral upbringing of children in Nigeria against the backdrop of corruption and insecurity. Using the moral approach to literary criticism, the paper examined the views of scholars on the importance of good children's literature right from the classical period to the contemporary era. Scholars have always believed that it is very important and pertinent that children are given good literature to read in order to help mold their morals at an early stage. The paper concluded by looking at how Echendu (2020) has used his children's prose Emeka and the Armed Robbers to inculcate good morals to his readers (children).
\end{abstract}

Keywords: Children's Literature, Moral Approach, Criticism, Corruption, Insecurity.

(C) 2021 Nnawuihe Fidelis Echendu. This is an open access article under the CC BY license (https://creativecommons.org/licenses/by/4.0/), which permits unrestricted use, distribution, and reproduction in any medium, provided you give appropriate credit to the original author(s) and the source, provide a link to the Creative Commons license, and indicate if changes were made.

\section{Introduction}

It is a well-known fact that corruption and insecurity are the twin evils that have rendered Nigeria's dream of economic and cultural development stillborn. Corruption, in particular, is responsible for Nigeria's present uninspiring underdeveloped status thus rendering the so called giant of Africa a laughing stock in the comity of nations.

In the early eighties, the then president of Federal Republic of Nigeria, Alhaji Shehu Shagari, recognizing the lethal potentials of this evil inaugurated a committee on Ethical Revolution to tackle this national pandemic (Nnolim, 1988). The Committee which was charged to seek ways of returning the nation to the path of moral and ethical rectitude ended a stillbirth, while corruption continued to rampage unabated and unchecked in the entire nation. Corruption rages on unabated in both private and public corporations and institutions.

As the Nigerian nation made a return to civil rule in 1999, the evil of insecurity began to rear its ugly head. It started like a child's play on the fringes of the nation's border with Chad and Niger Republic. The dreaded boko haram terrorists began to attack schools, churches, mosques and other government institutions in states along the border like Borno, Yobe, and Adamawa. Women and children were kidnapped in large numbers, while their men were either killed or taken by the terrorists to fight alongside them. Today, insecurity has spread out to the entire nineteen northern states leaving the entire region at the mercy of the terrorists. Farmers in the otherwise agrarian region have been forced to abandon their

\footnotetext{
* Corresponding author: Nnawuihe Fidelis Echendu, Department of Languages, Federal Polytechnic Bida, Nigeria. E-mail: echendu.fidelis@fedpoly.edu.ng
} 
homes and farms to live at Internally Displaced Persons' (IDP) camps. Other evils like kidnapping, armed robbery, banditry are wide spread in both northern and southern regions of the nation. As at this moment, it is widely reported by some national dailies in Nigeria that more than eighteen local government areas in the north east are under the control of these extremists.

Today, corruption and insecurity are perhaps the largest industry in Nigeria guzzling trillions of Naira annually. Nigerian government officials and their accomplices in the private sector loot dry the collective patrimony of the nation under the guise of fighting insecurity and stash away same in foreign bank accounts. Nothing explains this better than the jaw-dropping revelations of brazen lootocracy among government officials at the ongoing National Assembly probes. It is a well established truth that Nigerian Government has been pouring in trillions of naira since the year 2010 to check insecurity in the country without any tangible results. It would appear that these funds are looted by government officials and their contractors at the expense of the real security men and women whose lives are daily wasted by insurgents and terrorists on account of non availability of good ammunition.

Similarly, the ongoing investigation of the immediate past chairman of the Economic and Financial Crimes Commission (EFCC) by the Presidential Task Force is another example of brazen lootocracy by a Nigerian government official. The scandal which analysts have come to term "Magugate" is a case of re-looting of recovered funds which were previously looted by past government officials.

Closely related to terrorism is banditry and cattle rustling. These groups of non state actors operate in states like Kaduna, Zamfara, Niger, Katsina, Sokoto, Benue where they have worsened the already bad condition of the ordinary citizens. Almost on a daily basis, there are news reports of villages razed down by bandits leading to the swelling of the Internally Displaced Persons Camps. There are also the rampaging Fulani cattle herders who have killed scores of people especially in Southern Kaduna axis, Plateau, Benue, Nasarawa, Zamfara, Taraba, Kogi, Niger, Delta, Anambra, among other states. There are also several reported cases of kidnapping for ransom, rape, armed robbery, among other crimes. In the face of all these anomies, what should be the role of the creative writer, especially one that creates children literature?

\section{Theoretical conception}

According to the proponents of the moral approach to literary criticism, the literary works that we read affect us either positively or negatively depending on the author's intentions. In articulating this view, Eliot (cited in Scott, 1962) argues:

The author of a work of imagination is trying to affect us wholly, as human beings, whether he knows it or not; and we are affected by it, as human beings, whether we intend to be or not... (p. 48).

If the literature we read affects us as Eliot has informed us, it means that we must make sure that what we read is the right kind of literature; i.e., literature that teaches good morals. In line with this view, Wellek and Warren (1949) add that “...people may model their lives upon the patterns of fictional heroes and heroines. They have made love, committed crimes and suicide according to the book..." (p. 102).

The view that the works that we read influence our behavior is in consonance with Plato's argument in The Republic (Kaplan, 1986) where he insists that literature (which he calls poetry) is capable of corrupting morals especially among the young. Plato singles out Homer whom he criticizes severely for his anthropomorphic portrayal of Greek gods in his works; arguing that such depiction of the gods is capable of corrupting the minds of young Greeks against such gods so portrayed. He insists that Homer should either expunge the offensive depictions of the gods in his works or such works would never be taught at all to the young. It is quite obvious that Plato's concern as a critic is the inculcation of moral values by literary works among readers.

Similarly, Wellek and Warren (1949) drive the point home in their argument:

We can hypothesize- plausibly, no doubt- that the young are more directly and powerfully influenced by their reading than the old, that inexperienced readers take literature more naively as transcript rather than interpretation of life... (p. 102).

This situation calls for caution and carefulness in making available literature books for our young people to read. Put in computer language 'garbage in garbage out', what we give to our young people to read is tantamount to the expected outcome in terms of their behavior.

Bringing the argument home here in Nigeria in view of our present challenges such as insecurity, corruption etc., Nnolim (1988) argues that: 
In the face of despair which often grips us, I suggest a ray of hope is to be found in our literature. Why literature as a possible moral corrective? Why not more church sermons and more "moral instructions" in our schools? I lodge my hope in our literature because of the permanency of its nature and in the pervasive influence it has on the young and on our youths (p. 21).

Literature is thus viewed by these scholars as a moral corrective which could be deployed to help a society find its moral bearings. This can however be achieved if the literature in question is the right type, as we said earlier; the type that teaches the right morals.

Taking our argument down to the level of children literature, it is important to note that Achebe (2012) has urged the need for "children's books that have relevance to our society" (176). The question of "relevance" here relates to moral appropriateness and usefulness to society. This is especially important because children are in their formative years and are bound to accept whatever they are told in the books that they read. In view of this, Nwahunanya (1998) laments that:

...the literature addressed to children in Nigeria today has turned out to be of such appallingly low quality because of this absence of a systematized critical tradition that provides checks and balances for the writers (p. 118).

Nwahunanya (1988) goes ahead to lament situations where writers of children's literature in Nigeria manifest obvious obsession with pornography in their so-called children's books thus predisposing these children to loose morals thereby contributing substantially to the high level of moral degradation in the Nigerian society. In line with Anozie (1992), Nwahunanya (1988) criticizes both parents and the authorities in Nigeria who have obviously neglected their responsibility of ensuring that the literature produced for their children is the right kind, adding that "...since we recognize that the natural order is for children to succeed their parents, the need for adults to be interested in and concerned about children's literature becomes pressing" (p. 117).

In line with the foregoing, we shall examine my children prose Emeka and the Armed Robbers (2020) with my eyes on the relevance of the work with due regard to the moral and spiritual development of our children whom the book was written for.

\section{Didacticism in Emeka and the armed robbers}

Emeka and the Armed Robbers (2020) is a prose work which can be loosely classified as a story that teaches the virtue of hard work, vigilance, and honesty in the face of the present moral imbroglio in Nigeria. Emeka, a young boy growing up and attending a secondary school in the village is spurred up to success in his exams by the promise which his uncle makes to him. His uncle, James who is a trader based in Lokoja writes a letter to Emeka's father promising to take Emeka to Lokoja for his holidays, if he does very well in his Basic Certificate Examinations. This is all the encouragement that the young boy needs to spur him to success.

In order to achieve his dream of visiting Lokoja during the holidays as promised by his uncle, he takes action immediately. Hear him: "I stopped playing football during break time and at home in the evenings. I always made sure that all my notes were revised thoroughly every day before bed time" (p. 8). He studies so hard that his mother becomes worried:

Sometimes at home, my mother would beg me to leave my books a little and go out to play with my friends. She reasoned that 'all work no play' was not good for a growing child. But I refused to leave my books to play (p. 9).

Eventually, he writes the exam and emerges the best student in his school. With this result, the stage is now set for him to travel to Lokoja. The book is here teaching the virtue of hard work to children. As it is commonly said, hard work does not kill. Rather, it is the surest way to good success in life. The book is therefore showing before the children audience, a life picture of their fellow child who achieves his dream of success through diligence in his studies. The message is pointed: success awaits the diligent child.

While on the journey to Onitsha Park, from where he would board a night bus to Lokoja, Emeka notices the suffering of commuters in his southeast region due to bad roads and massive extortion by law enforcement officers:

The dirt road from my village to the express way leading to Onitsha was full of pools of water. They said the road was opened by the then Eastern Nigeria Government. But since that time, it had never been maintained even though it was now within the state capital territory. The other road we plied, the express way, was full of pot holes. This made the driver to be very slow as he was always dodging one pot hole or another (p. 14).

The condition of the roads in the southeast region of the nation as seen above is a sad reminder of the perennial neglect and abandonment of the region by subsequent governments since the end of the civil war in 1970. Sadly, the activities of policemen on the road do not escape his notice: 
Besides, there were numerous police check points on the road. At every check point, a policeman would approach the driver who would immediately squeeze twenty naira note into his hand and he would ask him to proceed. Drivers that had large denominations of the naira such as two hundred or five hundred naira would be asked to clear off the road, while another policeman would look for change for them. But for drivers that refused to comply, they were simply asked to park by the road side where they would remain until the policemen would decide what punishment to give to them (p. 15).

This anomalous situation actually gives the young boy goose bumps as he contemplates the daily suffering and hardship that his fellow country men and women go through on our roads while wondering what Nigerians had done to deserve this kind of treatment from the government and her agencies:

As I looked at all these from one check point to another, I pitied my fellow countrymen who endure such untold hardship silently without complaining. I wondered why the government should allow such day light robbery to be going on everywhere along our major roads without doing anything (p. 15).

By including this passage, I am instilling hatred for such social vices as bribery, extortion in the minds of his young readers. This is the technique of instilling discipline in children. As has been noted in the Holy Bible, when children are trained up in the way that they should go, they would hardly depart from that way when they grow old.

On his arrival at Lokoja, Emeka enjoys every bit of his stay there. His uncle and his family receive him very well. Consequently, he adjusts easily to life in the town. However, towards the end of his stay in the town, a gang of robbers attacks his uncle's estate and lives are lost. In his uncle's flat, the robbers steal some valuables aside the agony and trauma they (the robbers) subject the occupants of the house to. But unfortunately for two of the robbers, one of the residents of the estate shoots them, killing one and wounding one fatally. The robbers escape with their stolen items and their dead as well as injured gang members. For weeks, policemen are moving in and out of the estate in the name of investigation. But nothing comes out of the said investigation. Eventually, Aunty Rose falls sick and is taken to a private clinic on the outskirts of the town for treatment. Here again, the author beams his search light on what corruption has done to the country. Aunty Rose could not be taken to a government specialist hospital simply because medical doctors are on strike due to nonpayment of their entitlements. It is a well-known fact that health professionals in Nigeria are always on one form of strike or another. The same thing goes for teachers in higher institutions across the country. It appears that the Nigerian governments across the years can hardly hear or understand any other language other than strike. This has contributed to the unimaginable hardship which the citizens of the country go through on a daily basis. This too, does not escape the watchful eyes of the narrator.

While Aunty Rose is at the private hospital, Emeka and his cousins visit her to know how she is doing. It is in the course of this visit that Emeka discovers the injured robber whom he recognizes immediately he sees him. Uncle James quickly informs the police and the robber is arrested by the police.

When the case comes up in the court, the robbers plead guilty blaming the hardship in the country as responsible for their decision to take to robbery. They claim to be graduates of Nigerian universities who could not find jobs and therefore took to robbery as a means of survival. However, the trial judge sentences them to ten years imprisonment with hard labor. According to him, poverty cannot justify armed robbery or banditry. According to Emeka, the trial judge "... wondered why the robbers did not take their hoes and go to farm in order to earn their living" while pointing out the fact that "there was dignity in labor and that there was no law anywhere in the world against honest labor" (p. 53). The concluding part of the judgment is iconic as it etches on the mind of the young readers the need to shun vices while sticking to virtues. It also emphasizes the fact that there is no alibi for banditry, armed robbery, kidnapping etc.

\section{Conclusion}

The story highlights the twin challenge of corruption and insecurity in Nigeria. I am obviously concerned about the moral upbringing of children in view of the prevalent anomies in the land. In these days of widespread insecurity and corruption, it is necessary to educate and sensitize our children early in life thereby preparing them for the challenges they would face in the larger society. This helps them to take a strong and decisive stand against the twin evils of corruption and insecurity whenever necessary.

It is important to note that although Emeka's parents are poor, they however provide solid godly home training for their children. This is what later makes Emeka outstanding even as a young boy in his early teenage years. In my view, if parents could go the extra mile to inculcate positive values like diligence, godliness, hatred for corruption and social vices early enough in their children, they would have succeeded enormously in checking the violent tide of decaying moral values in our society. 


\section{References}

Achebe, C. (2012). There was a country. London: Penguin Books.

Anozie, O.S. (1992).The Drum and the flute: reconstruction in children's literature. Chidi, ikonne., Emelia, Oko., and Peter, Onwudinjo (Eds.), Children and Literature in Africa, Ibadan: Heinemann.

Echendu, W. (2020).Emeka and the armed robbers. Abuja: Caltop Publications.

Kaplan, C. (1986). Criticism: The Major Statements. New York: St Martins Press.

Nnolim, E.C. (1988). Moral values in the Nigerian novel. The Role of Education in Contemporary Africa. Ed. Charles Nnolim. New York: Paragon Press.

Nwahunanya, C. (1988). Issues in literary theory, history and criticism. Owerri: Corporate Impressions.

Scott, W.S. (1962). Five approaches of literary criticism. New York: Collier Books.

Wellek, R., and Warren, A. (1949). Theory of literature. Reading: Harcourt, Brace \& World.

Cite this article as: N nawuiheFidelis Echendu (2021). Using children's literature to combat corruption and insecurity in Nigeria. International Journal of Languages and Culture. 1(2), 14-18. doi:10.51483/ IJLC.1.2.2021.14-18. 